\title{
A Program Incorporating Physics, Astronomy and Environment
}

\author{
By Kononovich, E.V. ${ }^{1}$, Fadeeva, A.A. ${ }^{2}$, Kiselev, D.F. ${ }^{1}$ AND \\ Zasov, A.V.1
}

\author{
${ }^{1}$ Department of Physics, Moscow University, 119899, Moscow Russia \\ ${ }^{2}$ Institute of General Middle Education, Russian Educational Academy, 119906, Moscow, \\ Russia
}

A cultural role of astronomical education at all levels is well known and it is needless to repeat the corresponding arguments. Nobody denies it, but nobody can propose any universal way of introducing Astronomy on a level this branch of science deserves.

There is a good tradition to appreciate Astronomy in Russian schools. For more than a century part of the natural history science in school dedicated to the Universe has been considered as a separate part of the school curriculum in Russia. Before 1917 it was named Cosmography, and Astronomy thereafter. And up to now there is no decision or prescription to rule it out of the school program.

Nevertheless the teaching of Astronomy becomes less and less. Astronomy is taught only then and there where the enthusiasts of this subject are in existence. But the recent process of liberation of the educational system demands different approaches. Up to the present time several attempts to integrate astronomy with physics have not been very successful. The reason is the difference between their educational purposes.

The main purpose of this report is to emphasize the advantage of a somewhat more balanced program incorporating physics, astronomy and environment. Such a choice provides a more natural reason for integration, based on the ideal common to all three parts, to consider the world we live in as our home and property. The most general and fundamental ideas should be emphasized in such a course. As for astronomy, whose social importance is enormous in spite of the negligible teaching time, the necessary requirement is to elaborate a certain school minimum of astronomical knowledge.

As a first approximation we use our earlier elaborated and recently revised short textbook in Astronomy (Zasov and Kononovich, 1993) as a sum of basic astronomical information, principal ideas, and main teaching methods to introduce into this new type of project. The recently organised almanac "The Universe and Ourselves"(Kononovich, $1993,1995)$ might be very useful for supporting this program.

During the last decades an opinion has developed that Astronomy should be integrated with some other sciences. This works rather well for the primary school education, e.g. in Natural Science (Suravegina et al., 1994) where the Earth as a celestial object is successfully presented. But when we try to incorporate Astronomy into Physics usually we fail. Unfortunately it takes place even in the best courses (e.g. see Pinsky et al., $1993,1995)$. Theoretically this merger is quite possible but only when a special course of physics is concerned. Strictly speaking it is relatively easy to integrate only astrophysics with theoretical physics and no more. The traditional course of school physics differs from that of astronomy like, e.g. a modern theatre building from a Gothic cathedral. 
Time table of Physics and Astronomy in Natural Science complex

\begin{tabular}{|c|c|c|c|}
\hline Form & Year & Physical Level & Astronomical Level \\
\hline \multicolumn{4}{|c|}{$\begin{array}{l}\text { Elementary (Initial) School } \\
\text { "Surrounding World" }\end{array}$} \\
\hline 1 & 7 & $2 \ldots$ & \\
\hline 2 & 8 & Air Temperature & Time. Seasons. \\
\hline 3 & 9 & $\begin{array}{c}\text { Objects. Matter Solid. Air. } \\
\text { Liquid Water. }\end{array}$ & The Earth \\
\hline 4 & 10 & $\begin{array}{l}\text { Observations. Experiments. Tools. } \\
\text { Measurements. }\end{array}$ & The Earth from Space. Globe \\
\hline
\end{tabular}

\section{Middle (Main) School \\ "Natural Science"}

\begin{tabular}{|c|c|c|c|}
\hline 5 & 11 & $\begin{array}{r}\text { Mass. Density. Particles. Diffusion. } \\
\text { Interactions. }\end{array}$ & $\begin{array}{r}\text { Celestial objects. Solar System. } \\
\text { Ptolemeus and Kopernicus. The } \\
\text { Planet Earth. }\end{array}$ \\
\hline 6 & $\mathbf{1 2}$ & $\begin{array}{r}\text { Motion. Forces. Heat. Light. } \\
\text { Sound. Magnetism. }\end{array}$ & Origin of the Solar System. \\
\hline
\end{tabular}

The level of existing experiment: textbooks are available

"Physics. Astronomy. Environment

\begin{tabular}{|c|c|c|c|}
\hline 7 & 13 & Molecular physics. & $\begin{array}{c}\text { Astronomy. Universe overview. } \\
\text { Matter in space. Gas in the } \\
\text { Universe. The stars and the Sun. }\end{array}$ \\
\hline $\mathbf{8}$ & $\mathbf{1 4}$ & Mechanics & $\begin{array}{c}\text { Apparent sun, stars and planet } \\
\text { motions. Gravitation in the } \\
\text { Universe }\end{array}$ \\
\hline 9 & 15 & $\begin{array}{c}\text { Electricity and magnetism. Atomic } \\
\text { structure }\end{array}$ & $\begin{array}{c}\text { Solar, planetary and stellar magnetic } \\
\text { fields. Stellar interior }\end{array}$ \\
\hline
\end{tabular}

The level of existing experiment: experimental textbooks

High (Advanced) School

\begin{tabular}{|c|c|c|c|}
\hline 10 & 16 & $\begin{array}{c}\text { Mechanics. Thermodynamics. } \\
\text { Electrodynamics }\end{array}$ & $\begin{array}{c}\text { Celestial mechanics. Physical } \\
\text { properties of stellar and interstellar } \\
\text { gas. Cosmic electrodynamics. } \\
\text { Physics of Solar System }\end{array}$ \\
\hline 11 & 17 & Wave, atomic and quantum \\
physics & $\begin{array}{c}\text { The Sun and Stars. Interstellar } \\
\text { medium. Stellar Systems and the } \\
\text { Evolution the Universe. }\end{array}$ \\
\hline
\end{tabular}

The textbooks are in preparation

Figure 1. 
Certain aspects should be taken into account for a successful integration of astronomy with other subjects. We suggest as the most important among them the following:

1. Astronomy treats the largest space-time scales in the Universe.

2. Astronomy presents the Universe as the most general conception of the Environment and gives evidence of tight connection between Man and the Universe.

3. Astronomy proves the unity and the universal character of all fundamental laws of Physics.

These aspects may be treated as astronomical milestones on the educational road.

There are many attempts to present astronomy and/or physics using some other background. This is especially successful in fiction, science fiction, historical essays or textbook chapters and so forth. The course in Natural Science is also an example.

Positive results were obtained using poetry during lessons on Astronomy. Also for young children didactic material was prepared to support lessons on astronomical topics by means of paintings and drawings including those made by the pupils themselves. The main purpose of all these attempts is to stimulate childrens' interest and to make the education more humanistic.

Now we propose a new idea to use the Environment as a generalising background. It suggests treating the Universe as a whole as our living home, the widest subject of Environment we belong to. On the other hand Physics is a main tool to investigate the relations between the Universe and Ourselves.

The general outline of this project is summarised in the table (Fig. 1). It covers all three educational levels: Elementary (Initial), Advanced (Main) and High (Middle) school. The corresponding Russian titles of these educational levels are enclosed in brackets.

This program has been experienced in the frames of the two first levels and this is marked grey in the table (Fig. 1). It means that the permanent or experimental textbooks are available. Some of them are presented on this Colloquium as a poster.

Each educational period incorporates General Physics at the corresponding level: The course "Surrounding World" presents propaedeutical level for Elementary School (the first 4 years of education).

The course "Natural Science" presents an introductory level for the beginning of Middle School and for the time being is prepared in two variants:

1) as a two year program (Suravegina et al., 1993, 1994) and

2) as a three year program (Kalinova et al., 1991; Khripkova et al., 1992, 1994).

The course "Physics. Astronomy. Environment"presents an advanced level for the remaining years of education. It also consists of two independent cycles: one at the end of Middle School, the other during the whole High School.

The main problem of compiling such a course is to choose the right information corresponding to a given level. We try to follow the well known pedagogical principles, which make together a scientifically correct approach and a necessity to take into account pupils' abilities. Also we try to accumulate the educational material around fundamental physical conceptions, laws and theories to draw a general picture of the World in its integrity and unity. Astronomy presents an outstanding possibility to illustrate the evolution in the World over the widest space and time scales and extremely different stages from elementary particles to Homo Sapiens and further to cosmology. 


\section{REFERENCES}

Kalinova, G.S. et al, 1991, "Natural Science 5", Prosveschenie, Moscow.

Khripkova, A.G. et al, 1992, "Natural Science 6", Prosveschenie, Moscow.

Khripkova, A. G. et al, 1994, "Natural Science 7", Prosveschenie, Moscow.

Kononovich, E.V., 1993, "The Universe and Ourselves", Astronomical Society, Editor.

Almanac, No 1, Moscow.

1995, "The Universe and Ourselves", Astronomical Society, Editor.

Almanac, No 2, Moscow.

Pinsky, A.A. et al, 1993, "Physics and Astronomy 7", Prosveschenie, Moscow.

PINSKY, A.A. et al, 1995, "Physics and Astronomy 8", Prosveschenie, Moscow.

Suravegina, I.T. et al, 1993, "Natural Science 5. A Human Being and Natural Environment", Ecology and Education, Moscow.

Suravegina, I.T. et al, 1994, "Natural Science 6. A Human Being and Environment", Ecology and Education, Moscow.

Zasov, A.V \& Kononovich, E.V., 1993, "Astronomy 11", Prosveschenie, Moscow. 